ical laws and its attitude toward reciprocity (which he has never done at a meeting of the American Confederation), and audibly manifest a yearning for knowledge concerning the Illinois board which he has shown in his recent communication. The Illinois State Board of Health will be represented at this meeting, as she has been represented at meetings during the past sixteen years.

JAMES A. EGAN.

\section{The Medical Association of the Southwest.}

El Rexo, ORta., July 24, 1906.

To the Editor:-In keeping with the expressed wish and plan of the American Medical Association to organize the United States into several districts and to organize in these districts associations which will be allies to the American Medical Association, and because commercially, geographically and socially the several states grouped together here have for years been known as the Sonthwest, the state associations of Missouri, Kansas, Arkansas, Oklahoma-Indian Territory and Texas were askerl at the spring association meetings to appoint five men, who should be cnlled together to consider the advisability of such an organization. Fach state responded by appointing the desired number, and on July 16, at Kansas City, a meeting was called. Fourteen members responded, as follows: Drs. Jabez N. Jackson. Frank J. Lutz and Charles Wood Fassett, of Missouri; C. E. Bowers, George M. Gray, M. F. Jarrett and H. L. Alkire, of Kansas; T. E. Holland, J. A. Lightfoot and J. B. Bolton, of Arkansas; J. E. Gilcreest, of Texas; B. F. Fortner, of Indian Territory, and A. L. Blesh and F. H. Clark of Oklahoma. A temporary organization was effected, with Drs. F. J. Iutz, St. Louis, as president; J. T. Wilson, Sherman, Tex.; Marion King, Texarkana, Ark.; P. S. Mitchell, Iola; Kan., and C. S. Bobo. Norman, Okla., vice-presidents, and F. H. Clark, El Reno, Okla., secretary-treasurer.

A lengthy discussion was indulged in by all present as to the desirability of the contemplated move and all present noreed that it was the thing to do.

It was decided to hold the first general meeting of the association at Oklahoma City this fall, the exact date to be determined as soon as possible. A committee, composed of Drs. A. T, Blesh, Oklahoma; Jahez N. Jackson, Missouri; J. A. Lightfoot, Arkansas; C. F. Bowers. Kansas, and .T. E. Gilcreest. Texas, was appointed to draft a declaration of principles and a constitution and by-laws; the committee was requested to report the declaration of principles to the convention while in session and the constitution at the first general meeting of the association.

The committee reported the following declaration:

To the Medical Profession of the Southwest:-By virtue of the anthority delegated ns by our several state associations to consider the advisability of the formation of a medical assoriation of the southwest. and to define its purposes, scope and snhere of action, we, your committee. here, in pursuance of such instructions, this day met and beg leave to present the following conclusions: That the time is now opportune for the formation of a medical association of the southwest and respectfully urge that in consideration of the fact that the territory composed of the states of Missouri, Kansas, Arkansas. Oklahoma, Indian Territory and Texas are engaged in the active practice of the profession of med"cine between 15,000 and 20.000 of as bright and intelligent phrsicians as can be found anvwhere, who, hecause of the natural limitations of the state association on the one hand and the magnitude of the Amertean Association on the other, lack the proper opportunity for the full development of their powers.

We believe that the formation of an association of the states mentinned above will materially aid in developing this latent talent and thus advance the standard of scientific medicine in the whole and thus
nation.

We believe that the membersh'p of this association should be Iime believe that the membersh'p of this association good standlimited to those members of the nrofoss.

ing in their respective state assoriations. We believe that an gssoriatinn of this kind will satisfactorly
fill the present existing hiatus botween the state association on the one hand and the American Medieal Association on the other. occuthe its own, adaing increased effectiveness to the work of the one and at the same time training talent to adorn the other.

We would respectfully call the attention of the profession of the great southwest to the fact that this step is in harmony with the great southwest to the fact that this step is in harmoni with the idea expressed at the late meeting of the Ampriran Mediral Association and in its constitution (section vil) of dividing the United States Into districts. so as to make its work more effertive and

more trulv renre
the rnited states.

We would especialip call the attention of the profession to the fact that this association is not to be organized in opnosition to but rather tn harmony with, all existing regular associations.
We recommend that the name of this association be the Medical Association of the Southwest.

We invite the careful consideration of the medical profession of the states above mentioned to the reasons given, and if they meet with their approval extend a cordial invitation to them to join with us in making this. as it of right should be
est working medical bodies in the United States.

After a thorough discussion the declaration was unanimously adopted. A program committee was appointed, consisting of Drs. J. E. Gilcreest, J. D. Bolton, H. I. Alkire and the president and secretary.

Dr. H. C. Todd, Oklahoma City, was appointed chairman of the committee of arrangements, and the program committee was instructed to provide for the program in sections. The committee then adjourned to meet on the evening preceding the first session of the association at Oklahoma City, Okla. F. H. Clank, Secretary-Treasurer.

\section{The Gelatin Method of Preserving Specimens.}

Iow A CiTy, Towa, July 28, 1906.

To the Editor:-It appears that my article on the gelatin method of preserving specimens, which appeared in THE JourraL A. M. A., June 30,1906 , has created considerable interest as manifested by the communications of Professor Watters (see Tine Jolrnal A. M. A., July 14) and Dr. Hall (July 28).

In justice to Professor Watters I would like to say that I do not think that he claims to be the originator of the gelatin method of preserving specimens, but that he simply claims priority in the Petri-dish-glycerin-jelly method of mounting objects. In justice to myself, permit me to say that I did not claim in the original article to be the originator of the glycerin-jelly method of mounting specimens nor the first to conceive the idea of the use of the Petri-dish for that purpose. The idea of inclosing stained microscopic sections of the gross specimen in the preparation, and the special device attached to a hand microscope, making it possible to examine the gross and microscopic preparations at the same time, are not only original with me, but so far as I know, no mention of them has ever appeared in print previous to the publication of my article. These being very desirable modifications or rather additions to the Petri-dish-gelatin method, I considered that it was entirely legitimate to speak of it as "A New Method of Mounting Museum Preparations."

\section{Henry Alrert, M.D.}

\section{Hay-fever Treatment by Dunbar's Remedies (Pollantin).}

Chicago, July 23, 1906.

To the Editor:-As the hay-fever season approaches, physicians are interested in any remedy which promises to give their patients relief. Much has been published during the last three years of the treatment devised by Professor Dunbar, and many physicians have given it an extensive trial, I among the number; but I cannot subscribe to the extravagant statements that have been made in its favor.

Three years ago I tried the serum on several patients, but without effect. Year before last I tried the pollantin powder (the dried serum) in a number of cases, and in only one did I get a report that it had done good.

At the 1905 meetings of the American Laryngological Association and of the Americal Laryngological, Rhinological and Otological Society, the subject of the treatment of hay-fever by these remedies was under discussion. In each of these meetings there were from 30 to 50 laryngologists present. In both instances there were one or two members who spoke with some favor of the use of pollantin and ascribed the poor results of treatment by pollantin the previous year to the quality of the remedy used, it being stated that for those persons who were affected by the pollen of certain grasses or ragweed a different pollantin should be used from that adapted for those who were affected by the pollen of the golden rod. No one else in either of these meetings appeared to have any confidence in the results to be obtained from these remedies.

I came away from both meetings with the feeling that pos. sibly I had not been careful enough in my direction to patients who were to use the remedy, and that I had probably not had 